\title{
Efficacy of Seed Size to Improve Field Performance of Wheat under Late Sowing Conditions
}

\author{
Muhammad Muhsin', Muhammad Nawaz ${ }^{2}$, Imran Khan ${ }^{1}$, Muhammad Bilal Chattha ${ }^{3}$, Sadia Khan ${ }^{4}$, \\ Muhammad Talha Aslam ${ }^{1}$, Muhammad Mahmood Iqbal ${ }^{5}$, Muhammad Zubair Amin ${ }^{6}$, Muhammad Ahsin \\ Ayub $^{7}$, Usman Anwar ${ }^{8}$, Muhammad Umair Hassan ${ }^{1}$ and Muhammad Umer Chattha ${ }^{1 *}$
}

${ }^{1}$ Department of Agronomy, University of Agriculture, Faisalabad, 38040, Pakistan; ${ }^{2}$ Department of Agricultural Engineering, Khwaja Fareed University of Engineering and Information Technology, Rahim Yar Khan 64200, Pakistan; ${ }^{3}$ Institute of Agricultural Sciences, The University of Punjab, Lahore, Pakistan; ${ }^{4}$ Department of Agriculture, Government of Punjab, Lahore, Pakistan; ${ }^{5}$ Cotton Research Institute Multan, Pakistan; ${ }^{6}$ Department of Agricultural Extension Agriculture University of Agriculture, Faisalabad, 38040, Pakistan; ${ }^{7}$ Rice Research Station, Babawalnagar, 62031, Pakistan; ${ }^{8}$ Wheat Research Institute, Ayub Agricultural Research Institute (AARI), Faisalabad, Pakistan

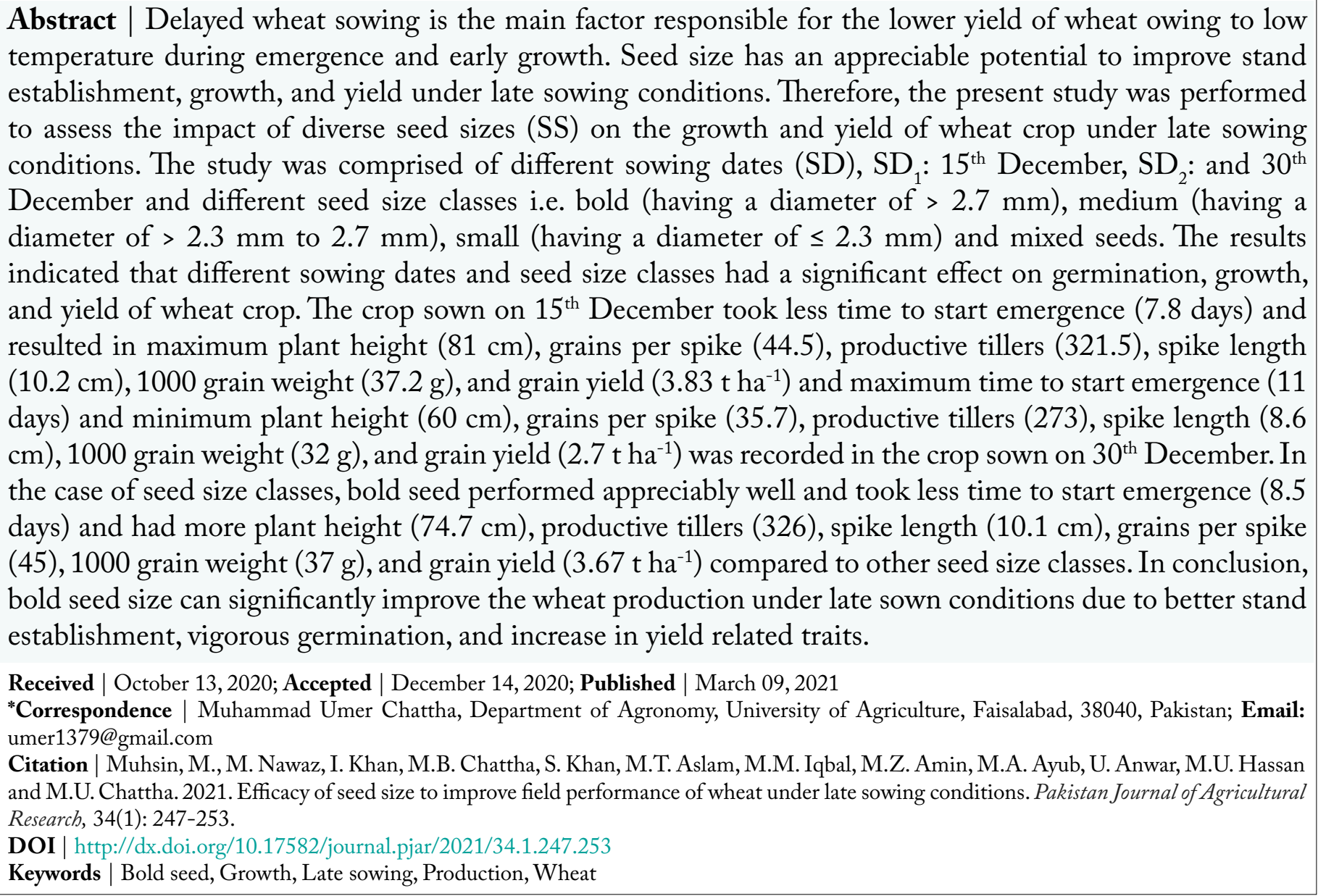

Introduction

W Theat is a major grain crop and primary staple food of Pakistan and it is a major source of carbohydrates and energy (Chattha et al., 2017a, 2018). The seed of wheat contains 2.11\% minerals, $68 \%$ carbohydrate, $2.9 \%$ fat, $15.4 \%$ proteins and an important source of calories and micro-nutrients 
(Anjum et al., 2005; Chattha et al., 2017b; Hassan et al., 2019). An increase in the productivity of wheat crop is a foremost aspect to feed the growing population and to eliminate malnutrition. However, different factors including the poor nutrient management, sowing times, late harvesting of cotton, non-availability of higher yielding varieties, and disease attack significantly reduced the wheat yield (Chattha et al., 2017; Zain et al., 2017).

Among these factors; sowing time plays an essential role in the growth and productivity of the wheat crop, and the optimum sowing time leads to higher productivity without incurring additional costs (Ouda et al., 2016). Normal sowing provides more time for tillering and resulting in more tillers, spikes, grain weight, grains per ear and consequently the higher yield (Qasim et al., 2008). Early sowing of wheat produces weak tillers with deprived root system due to high temperature which also causes poor germination and death of an embryo. Late sowing causes weak tillering and slow plant growth due to low temperature (Tahir et al., 2009) which resulted in poor germination, stand establishment (Timmermans et al., 2007) and consequently leads to lower production (Farooq et al., 2008). Moreover, late sowing also reduced tillering and increases the chances of injury during winter (Joshi et al., 1992) and favors the disease attack which triggers the lower production (Gul et al., 2012). Additionally, late planting of wheat disrupts the connection between source and sink (Sial et al., 2005), and the crop is often exposed to heat stress during grain filling stages which causes a substantial reduction in yield and quality (Savin et al., 1996; Hassan et al., 2020).

Poor crop establishment is a major problem for the lower wheat production under late sown conditions, however, sowing of good quality seeds is a costeffective method to improve stand establishment and yield under these conditions (Chivasa et al., 1998). Seed size is an essential component of seed quality which affects plant performance in the context of germination, growth, and yield (Adebisi et al., 2011). Likewise, bold seeds are considered to be more vigorous and they have higher germination and yield potential compared to the smaller seeds (Khurana and Singh, 2001). Bold seeds contain a large amount of food reserves than small and medium-sized seeds (Gunaga et al., 2011), which favors better germination and subsequent growth and yield. However, a little research work has been done to determine the effect of seed sizes on the performance of late-planted wheat crop grown in semi-arid areas. Therefore, considering, the importance of all these facts and problems, this research was planned to determine the impact of different seed sizes on growth and yield of wheat under late sown conditions.

\section{Materials and Methods}

\section{Experimental site and design}

The research work was done at the Agronomy Farm, University of Agriculture, Faisalabad, Pakistan during the rabi season of 2018-19. The randomized complete block design (RCBD) with split plot arrangements was used to perform the trail with three replications. The studied site has a semi arid hot climate furthermore the weather conditions during the growing season are given in Figure 1. The soil samples from the diverse parts of experimental field were collected with the help of an auger and subjected to determine different physio-chemical properties by following the standard procedures of Homer and Pratt (1961). The experimental soil had sandy loam texture with $\mathrm{pH} 7.8$, organic matter $0.83 \%$, available phosphorus $4.7 \mathrm{mg} \mathrm{kg}^{-1}$, available potassium $170 \mathrm{mg}$ $\mathrm{kg}^{-1}$, and total nitrogen $0.03 \%$.

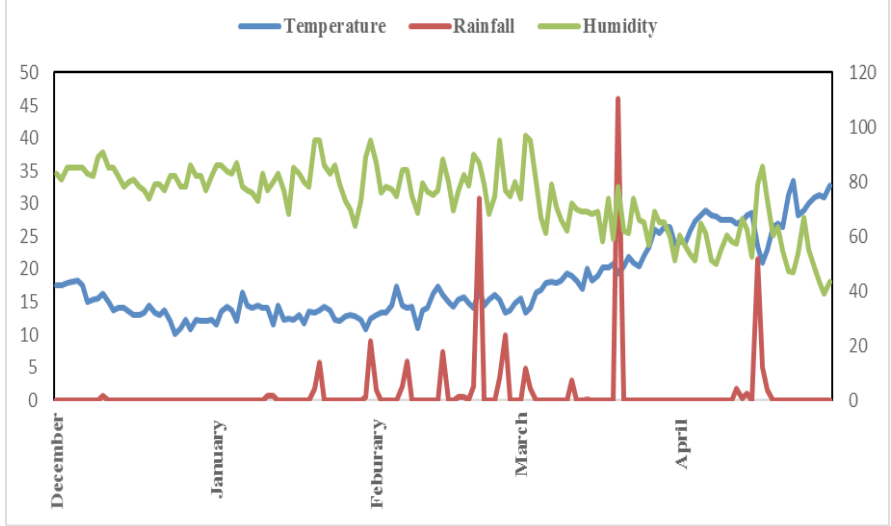

Figure 1: Weather conditions during the crop growth period.

\section{Treatments and plant material}

The experiment consisted of different sowing dates, i.e., $\mathrm{SD}_{1}=15^{\text {th }}$ December, $\mathrm{SD}_{2}=30^{\text {th }}$ December, and seed sizes i.e., $\mathrm{S}_{1}=$ bold $(>2.7 \mathrm{~mm}), \mathrm{S}_{2}=$ medium $(2.7 \mathrm{~mm})$ and $\mathrm{S}_{3}=$ small $(<2.3 \mathrm{~mm}) \mathrm{S}_{4}=$ mixed seed. The seed of variety Punjab-2011 was collected from Ayub Agricultural Research Institute, Faisalabad. Three seed classes such as bold, small, and medium seed were obtained by grading the seed with the help of a seed grader. 
Crophusbandry

The field was cultivated 2-times followed by planking to prepare the final seedbed. The recommended seed rate of $125 \mathrm{~kg} / \mathrm{ha}^{-1}$ was used and sown with a hand drill in $22.5 \mathrm{~cm}$ apart rows. Fertilizers were applied after conducting soil analysis at the rate of 100:80:60 kg NPK ha ${ }^{-1}$ respectively. Single superphosphate (SSP) $(18 \% \mathrm{P})$ urea $(46 \% \mathrm{~N})$, and sulfate of potash $(50 \% \mathrm{~K})$ were applied as a fertilizer. All the $\mathrm{P}, \mathrm{K}$, and $1 / 3$ of the $\mathrm{N}$ fertilizers were applied as basal dose rest of $\mathrm{N}$ was applied twice (at tillering and booting stage). In total four irrigations were applied to the crop for attaining better growth.

\section{Observations}

The plots were visited daily after sowing to note the time to start emergence. A unit area $\left(\mathrm{m}^{2}\right)$ was marked in each plot and tillers were counted at final harvesting. Similarly, ten plants were chosen from each plot and their height was measured and averaged. Ten spikes were taken and their length was measured and the number of grains was counted. The crop was harvested and weighed to determine biological yield and grain yield and later on converted into $t \mathrm{ha}^{-1}$.

\section{Statistical analysis}

The collected data on different traits were statistically evaluated by using Fisher's analysis of variance and means were separated by the least significant difference test at 5 percent probability level (Steel et al., 1997).

\section{Results}

The results indicated different $\mathrm{SD}$ and seed size (SS) had a significant impact on the time to start germination (TSG) (Table 1). The maximum TSG (10.50 days) was taken by seed sown on $30^{\text {th }}$ December and the lowest TSG was taken by crop sown on $15^{\text {th }}$ December (Table 1). In the case of SS maximum TSG (10.16 days) was taken by small seeds after that mix seeds and lowest TSG (8.5 days) was taken by bold seeds (Table 1). Similarly, the diverse SD and SS also significantly affected the growth and yield traits. Taller plants $(81 \mathrm{~cm})$ were noticed in crop sown on $15^{\text {th }}$ December and the shortest plants $(59.75 \mathrm{~cm})$ were noticed in crops sown on $30^{\text {th }}$ December (Table 1). Among, SS maximum plant height $(74.63 \mathrm{~cm})$ was noted in bold seeds after that medium seeds that were remained same with medium, small, and mixed sees and minimum plant height $(67 \mathrm{~cm})$ was noticed in small seeds (Table 1 ).
Table 1: Effect of different sowing dates and seed size on Plant height, productive tillers, spike length.

\begin{tabular}{|c|c|c|c|c|}
\hline $\begin{array}{l}\text { Sowing dates } \\
\text { (SD) }\end{array}$ & $\begin{array}{l}\text { Time to start } \\
\text { emergence } \\
\text { (days) }\end{array}$ & $\begin{array}{l}\text { Plant } \\
\text { height } \\
\text { (cm) }\end{array}$ & $\begin{array}{l}\text { Productive } \\
\text { tillers }\left(\mathrm{m}^{-2}\right)\end{array}$ & $\begin{array}{l}\text { Spike } \\
\text { length } \\
(\mathrm{cm})\end{array}$ \\
\hline $15^{\text {th }}$ December & $7.92 \mathrm{~b}$ & $81.00 \mathrm{a}$ & $321 \mathrm{a}$ & $10.26 \mathrm{a}$ \\
\hline $30^{\text {th }}$ December & $10.50 \mathrm{a}$ & $59.75 b$ & $273 b$ & $8.658 b$ \\
\hline $\mathrm{LSD} \leq 0.05 \mathrm{P}$ & 0.36 & 4.30 & 43.11 & 0.49 \\
\hline \multicolumn{5}{|l|}{ Seed Sizes (SS) } \\
\hline Bold & $8.50 c$ & $74.63 a$ & $326 a$ & $10.13 a$ \\
\hline Medium & $9.33 b$ & $70.37 \mathrm{~b}$ & $299 b$ & $9.48 \mathrm{~b}$ \\
\hline Small & $10.16 \mathrm{a}$ & $67.00 \mathrm{~b}$ & $271 c$ & $8.51 c$ \\
\hline Mixed & $8.83 b c$ & $69.50 \mathrm{~b}$ & $292 b$ & $9.70 \mathrm{~b}$ \\
\hline $\mathrm{LSD} \leq 0.05 \mathrm{P}$ & 0.66 & 3.49 & 19.83 & 0.27 \\
\hline $\mathrm{SD} \times \mathrm{SS}$ & NS & NS & NS & NS \\
\hline
\end{tabular}

The maximum productive tillers $\left(321.5 \mathrm{~m}^{2}\right)$ and spike length $(10.25 \mathrm{~cm})$ were noticed in crops sown on $15^{\text {th }}$ December, and lowest productive tillers $\left(273 \mathrm{~m}^{2}\right)$ and spike length $(8.66 \mathrm{~cm})$ were noticed in crop sown on the $30^{\text {th }}$ December (Table 1). Amongst SS; maximum productive tillers $\left(326.1 \mathrm{~m}^{2}\right)$ and spike length (10.13 $\mathrm{cm})$ were noticed in bold seeds after that medium seeds and minimum tillers $\left(271.7 \mathrm{~m}^{2}\right)$ and spike length $(8.51 \mathrm{~cm})$ was noticed in small seeds (Table 1). The effect of different SD and SS on grains/spike and thousand grain weight (TGW) was significant. Maximum grains/spike (44.58) and TGW (37.18 g) was noticed in crop sown on $15^{\text {th }}$ December, and the lowest grains/spike (35.75) and TGW (31.96 g) was recorded from crop sown on the $30^{\text {th }}$ December (Table 2). The maximum grains/spike (45.17) and TGW (36.97 g) was produced by bold seeds after that medium seeds and lowest grains/spike (34) and TGW (32.03 g) were recorded from the small seeds (Table 2).

The results indicated that SD and SS had a significant impact on the biological and grain yield and harvest index (Table 2). The maximum biological yield (8.75 $\mathrm{t}$ $\left.\mathrm{ha}^{-1}\right)$ and grain yield $\left(3.83 \mathrm{tha}^{-1}\right)$ were obtained from crop sown on $15^{\text {th }}$ December and lowest biological yield $\left(6.86 \mathrm{t} \mathrm{ha}^{-1}\right)$ and grain yield $\left(2.68 \mathrm{tha}^{-1}\right)$ were noticed from the crop sown on the $30^{\text {th }}$ December (Table 2). Amongst SS; bold seeds performed appreciably well and resulted in maximum biological yield $\left(8.27 \mathrm{t} \mathrm{ha}^{-1}\right)$ and grain yield $\left(3.67 \mathrm{t} \mathrm{ha}^{-1}\right)$ after that medium seeds and lowest biological $\left(7.44 \mathrm{t} \mathrm{ha}^{-1}\right)$ 
and grain yield (2.83 $\left.\mathrm{tha}^{-1}\right)$ was noticed in small seeds (Table 2). Maximum harvest index (HI) (43.76\%) was recorded in crop sown on $15^{\text {th }}$ December and lowest HI $(39.05 \%)$ was recorded in crop sown on $30^{\text {th }}$ December. Amongst SS; maximum HI (44.43\%) was noticed for bold seeds that was comparable with medium seed size class and the lowest HI (38.81\%) was noticed in small seeds (Table 2). The data were subjected to the Pearson correlation analysis (Table 3). A negative correlation was recorded between TSE and all the studied traits, whilst the rest of all the parameters have a positive association with each other (Table 3).

\section{Discussion}

Sowing dates and seed size classes had a significant impact on the emergence, subsequent growth and yield of wheat crop. Late sowing delayed the wheat germination and subsequent seedling emergence due to restricted various physiological and metabolic processes (Akhtar et al., 2012), which, therefore, resulted in a subsequent reduction in final production. Bold seeds took less time to emerge compared to all the other seed types (Table 1). Bold seeds are considered to be more vigorous and have a large quantity of stored reservoirs which favors the metabolic process and therefore, triggers better and early emergence (Mustafa et al., 2018). The various SD and SS significantly affected plant height and tillers production. Late sowing considerably reduced the plant height owing to a lower temperature at the early stages which restricted the process of photosynthesis and leads to a reduction in the production of assimilates which in turn substantially reduced the vegetative growth (Mumtaz et al., 2015; Kalwar et al., 2018). Bold seeds achieved greater early growth, making plants more competitive against weeds and pest attacks and therefore, ensure better growth and development (Rukavin et al., 2002).

Table 2: Effect of different sowing dates and seed size on number of grains per spike, 1000-grain weight, biological yield and grain yield.

\begin{tabular}{|c|c|c|c|c|c|}
\hline Sowing dates (SD) & Grains per spike & 1000-grain weight (g) & Biological yield $\left(t^{h} a^{-1}\right)$ & Grain yield $\left(\mathrm{t} \mathrm{ha}^{-1}\right)$ & Harvest index \\
\hline $15^{\text {th }}$ December & $44.58 \mathrm{a}$ & $37.18 \mathrm{a}$ & $8.75 \mathrm{a}$ & $3.83 \mathrm{a}$ & $43.76 \mathrm{a}$ \\
\hline $30^{\text {th }}$ December & $35.75 \mathrm{~b}$ & $31.96 \mathrm{~b}$ & $6.85 \mathrm{~b}$ & $2.68 \mathrm{~b}$ & $39.05 b$ \\
\hline $\mathrm{LSD} \leq 0.05 \mathrm{P}$ & 1.43 & 3.46 & 1.19 & 0.22 & 3.22 \\
\hline \multicolumn{6}{|l|}{ Seed Sizes (SS) } \\
\hline Bold & $45.17 \mathrm{a}$ & $36.97 \mathrm{a}$ & $8.27 \mathrm{a}$ & $3.67 \mathrm{a}$ & $44.43 \mathrm{a}$ \\
\hline Medium & $42.16 \mathrm{~b}$ & $34.35 b$ & $7.75 \mathrm{~b}$ & $3.38 \mathrm{~b}$ & $43.65 \mathrm{a}$ \\
\hline Small & $34.00 \mathrm{~d}$ & $32.03 c$ & $7.45 \mathrm{c}$ & $2.83 \mathrm{~d}$ & $38.81 \mathrm{c}$ \\
\hline Mixed & $39.33 c$ & $34.97 \mathrm{~b}$ & $7.75 \mathrm{~b}$ & $3.13 c$ & $40.03 b$ \\
\hline $\mathrm{LSD} \leq 0.05 \mathrm{P}$ & 1.84 & 1.76 & 0.23 & 0.24 & 1.90 \\
\hline $\mathrm{SD} \times \mathrm{SS}$ & NS & NS & NS & NS & NS \\
\hline
\end{tabular}

Means with different letters differed 0.05 P level. NS: non-significant

Table 3: Pearson correlation among the studied traits.

\begin{tabular}{|c|c|c|c|c|c|c|c|c|c|}
\hline Variables & TSE & PH & PT & SL & GPS & TGW & BY & GY & HI \\
\hline TSE & 1 & & & & & & & & \\
\hline PH & $-0.96^{* *}$ & 1 & & & & & & & \\
\hline PT & $-0.93^{*}$ & $0.90^{* *}$ & 1 & & & & & & \\
\hline SL & $-0.96^{*}$ & $0.90^{*}$ & $0.92^{*}$ & 1 & & & & & \\
\hline GPS & $-0.91^{*}$ & $0.86^{* *}$ & $0.98^{* *}$ & $0.93^{* *}$ & 1 & & & & \\
\hline TGW & $-0.97^{* *}$ & $0.93^{* *}$ & $0.97^{* *}$ & $0.96^{*}$ & $0.96^{* *}$ & 1 & & & \\
\hline BY & $-0.96^{* *+}$ & $0.99^{* *}$ & $0.92^{* *}$ & $0.90^{* *}$ & $0.88^{* * *}$ & $0.95^{* *}$ & 1 & & \\
\hline GY & $-0.94^{* * *}$ & $0.96^{* *}$ & $0.96^{* \prime}$ & $0.94^{* *}$ & $0.95^{* * *}$ & $0.96^{* *}$ & $0.97^{\text {sto }}$ & 1 & \\
\hline $\mathrm{HI}$ & $-0.82^{* *}$ & $0.81^{* *}$ & $0.92^{* *}$ & $0.88^{* *}$ & $0.96^{*}$ & $0.87^{*}$ & $0.81^{* *}$ & $0.93^{* *+}$ & 1 \\
\hline
\end{tabular}

TSE: time to start emergence, PH: plant height, PT: productive tillers, SL: spike length, GPS: grains per spike, TGW: 100 grain weight, BY: biological yield, GY: grain yield, HI: barvest index. 
In late planting, tillering was decreased owing to the fact as the temperature was gradually increased and sensitivity to high temperature was also increased which in turn reduced the tillering production in wheat (Kalwar et al., 2018). Moreover, bold seeds had maximum tillers compared to other seed types. Bold seed ensures adequate plant populations across the wide range of field conditions and therefore, leads to a substantial increase in the tillers production, whilst small seeds are less vigor and have poor germination which triggers lower tillering Gan and stobbe (1995). Late planting also reduced the spike length and grains/ spike due to the shorter growing period and increase in temperature at the reproductive stage causes the reduction in seed production (Shahzad et al., 2007). Moreover, a short growing period also favors the less assembly of assimilates in the smaller growing period and heat stress at later stages due to late sowing also induced the pollen abortion and sterility and therefore resulted in fewer seeds/spike (Dhaka et al., 2006).

Late sowing also caused a substantial reduction in the grain weight, grain and biological yield. Late sowing shrinks the length of the growing period, which eventually decreased the grain filling period and also provides less time for photo-assimilates to move toward the sink which resulting in less kernel weight (A1-Karaki et al., 2007; Hossain et al., 2012). Bold seeds also resulted in maximum grain weight compared to other seed size classes (Table 2). Bold seeds produced healthier seedlings and uniform stand establish and favor the better assimilates production and consequently leads to the production of seeds weight with more weight (Shahwani et al., 2014). Late planting also reduced the biological and grain yield (Table 2). The reduction in biological yield in late planting can be due to less emergence, poor stand establishment and low tillers production which are correlated with previous outcomes of Anwar et al. (2015) they also concluded that biological yield decreased in late sowing owing to the shorter growing season, poor stand establishment and less tillering. Moreover, the maximum biomass yield was noted in bold seeds owing to higher emergence, better stand establishment, and higher tillers compared to other seed size classes (Zareian et al., 2013).

Late sowing also led to a significant reduction in grain yield and harvest index. Poor growth in late-planted wheat and heat stress at post-anthesis stage induced the reduction in tillers production, seed weight, and other yield contributing traits which consequently leads to a reduction in grain yield (Shirpurkar et al., 2007;
Baloch et al., 2012). The grain yield is the function of many yields contributing traits and the maximum grain yield was noticed in bold seeds which can be due to higher tillers production, better grains/spike, spike length, and grain weight as compared to other SS classes (Stougaard and Xue, 2004). A substantial reduction in harvest index $(\mathrm{HI})$ was noticed in late sowing which can be due to a reduction in grain and seed yield (Andarzian et al., 2015). Moreover, the maximum HI was reported in bold seeds which can be due to higher grain and biological yield.

\section{Conclusions and Recommendations}

The results indicated that delaying sowing led to a significant reduction in the growth and productivity of wheat. The seed size classes had clear differences in the context of growth and productivity. The bold seeds performed appreciably well and resulted in maximum improvement in growth and yield compared to other seed size classes. Therefore, the bold seed size can improve wheat productivity under late sown conditions due to vigorous germination and an increase in yield related traits. However, more studies should be conducted on diverse soils and agroecosystems prior to make it a recommendation for the farming community.

\section{Novelty Statement}

Limited information is available about the effect of different seed sizes classes on the performance of lateplanted wheat crop grown in semiarid areas. Therefore, this study was performed to underpin the impact of seed sizes on growth and yield of wheat under late sown conditions.

\section{Author's Contribution}

Muhammad Muhsin, Muhammad Umer Chattha and Imran Khan: Conducted the experiment and write the original draft.

Muhammad Nawaz, Muhammad Bilal Chattha, Sadia Khan, Muhammad Mahmood Iqbal, Muhammad Ahsin Ayub and Usman Anwar: Review and editing.

Muhammad Talha Aslam and Muhammad Zubair Amin: Helped in data collection.

Muhammad Umair Hassan: Wrote the original draft.

Conflict of interest

The authors have declared no conflict of interest. 
zinc deficiency. Front. Plant Sci., 8: 281.https:// doi.org/10.3389/fpls.2017.00281

Adebisi, M.A., T.O. Kehinde, M.O. Ajala, E.F. Olowu and S. Rasaki. 2011. Assessment of seed quality and potential longevity in elite tropical soybean (Glycine max L.) Merrill grown in Southwestern Nigeria. Niger. Agric. J., 42: 94103.

Akhtar, M., N. Ahmad, M. Nasrullah, B. Ali, A.R. Zahid and M.I. Shahid. 2012. Effect of late planting on emergence, tillering and yield of various varieties of wheat. J. Anim. Plant Sci., 22(4): 1163-1166.

Al-Karaki, G.N.,A.Al-Ajmi and Y.Othman.2007. Seed germination and early root growth of three barley cultivars as affected by temperature and water stress. Am. Eurasian J. Agric. Environ. Sci., 2: 112-117.

Andarzian, B., G. Bannayan, M. Shirali and B. Andarzian. 2015. Determining optimum sowing date of wheat using CSM-CERESWheat model. J. Saudi Soc. Agric. Sci. 14: 189199.

Anjum, F.M., I. Ahmad, M.S. Butt, M.A. Sheikh and I. Pasha. 2005. Amino acid composition of spring wheat and losses of lysine during chapatti baking. J. Food Nutr., 18: 523-532. https://doi. org/10.1016/j.jfca.2004.04.009

Anwar, S., W.A. Khattak, I.M. Islam, S. Bashir, M. Shafi and J. Bakht. 2015. Effect of sowing dates and seed rates on the agro-physiological traits of wheat. J. Environ. Earth Sci., 5: 135-141.

Baloch, M.S., M.A. Nadim, M. Zubair, I.U. Awan, E.A. Khan and S.Ali.2012. Evaluation of wheat under normal and late sowing conditions. Pak. J. Bot., 44(5): 1727-1732.

Chattha,M.U.,H.Ali,M.U.Chattha,M.U.Hassan, M.B. Chattha, M. Nawaz and S. Hussain. 2018. Combined application of distillery spent wash, bio-compost and inorganic fertilizers improves growth, yield and quality of wheat. J. Anim. Plant Sci., 28: 1112-1120.

Chattha, M.U., M.B. Chattha, I. Khan, U. Anwar, M.U. Hassan, M. Nawaz, S.A. Anjum, A. Mahmood and S. Mirza. 2017a. Effect of seeding rate and seed soaking duration on productivity of relay-intercropped wheat in cotton. Pak. J. Sci., 69: 190-194.

Chattha, M.U., M.U. Hassan, I. Khan, M.B. Chattha, A. Mahmood, M. Nawaz, S. Khan, M.N. Subhani and M. Kharal. 2017b. Biofortification of wheat cultivars to combat
Chivasa, W., D. Harris, C. Chiduza, P. Nyamudeza and A.B. Mashingaidze. 1998. Agronomic practices, major crops and farmers' perceptions of the importance of good stand establishment in Musikavanhu Communal Area, Zimbabwe. J. Appl. Sci. South Afr., 4: 9-25. https://doi. org/10.4314/jassa.v4i2.16901

Dhaka, A.K., A.S. Bangarwa, R.K. Pannu, R.K. Malik and R. Garg. 2006. Phenological development, yield and yield attributes of different wheat genotypes as influenced by sowing time and irrigation levels. Agric. Sci. Digest., 26: 174-177.

Farooq, M., S.M.A. Basra, H. Rehman and B.A. Saleem. 2008. Seed priming enhancement the performance of late sown wheat by improving chilling tolerance. J. Agron. Crop Sci., 194: 55-60. https://doi.org/10.1111/j.1439037X.2007.00287.x

Gan, Y. and E.H. Stobbe. 1995. Effect of variations in seed size and planting depth on emergence, infertile plants' and grain yield of spring wheat. Can. J. Plant Sci., 75: 565-570. https://doi. org/10.4141/cjps95-098

Gul,H.,B.Saeed,A.Z.Khan,B.Haleema,L.Parveen and N.L. Badshah. 2012. Morphological and some yield attributes in cultivars of wheat in response of varying planting dates and nitrogen application. J. Agric. Bio. Sci., 7: 100-109.

Gunaga, R., P. Doddabasava and R. Vasudeva, 2011. Influence of seed size on germination and seedling growth in Mammea suriga. Karnataka J. Agric. Sci., 24: 415-416.

Hassan, M.U., M.U. Chattha, A. Ullah, I. Khan, A. Qadeer, M. Aamer, A.U. Khan, F. Nadeem and T.A. Khan, 2019. Agronomic biofortification to improve productivity and grain $\mathrm{Zn}$ concentration of bread wheat. Int. J. Agric. Biol., 21: 615-620.

Hassan, M.U., M.U. Chattha, I. Khan, M.B. Chattha, L. Barbanti, M. Aamer, M.M. Iqbal, M. Nawaz, A. Mahmood, A. Ali and M.T. Aslam. 2020. Heat stress in cultivated plants: nature, impact, mechanisms, and mitigation strategies-a review. Plant Biosyst., pp. 1-24. https://doi.org/10.1080/11263504.2020.1727 987

Homer, C.D. and P.F. Pratt. 1961. Methods of analysis for soils, plants and waters. University of California. Agric. Sci. Publications, Berkeley. 
Hossain, A., J.A. Teixeira-da-Silva, M.V. Lozovskaya and V.P.Zvolinsky.2012. The Effect of high temperature stress on the phenology, growth and yield of five wheat (Triticum aestivum L.) genotypes. Asian Aust. J. Plant Sci. Biotech., 6: 14-13.

Joshi,A.K., B. Rai and M.P. Sing, 1992. Technology for late sowing wheat in eastern Uttar Perdesh. Indian Farm., 42: 15.

Kalwar, Z.A., A. Tunio, M.Y. Shaikh, I. Khan, Jatoi and Q.Jogi.2018. Impact of sowing dates on the growth and yield of wheat variety benazir-2013, Sindh Province, Pakistan. Int. J. Agron. Agric. Res., 12: 65-71.

Khurana, E. and U.S. Singh. 2001. Ecology of seed and seedling growth for conservation and restoration of tropical dry forest. Environ. Conserv., 28: 39-52. https://doi.org/10.1017/ S0376892901000042

Mumtaz, M.Z., M. Aslam, H.M. Nasrullah, M. Akhtar and B. Ali.2015. Effect of various sowing dates on growth, yield and yield components of different wheat genotypes. Am. Eurasian J. Agric. Environ. Sci., 15(11): 2230-2234.

Mustafa, A., R. Ahmad, M. Farooq and A. Wahid. 2018. Effect of seed size and seed priming on stand establishment, wheat productivity and profitability under different tillage systems. Int. J. Agric. Biol., 20: 1710-1716.

Ouda, S., X. Zhang, S. Chena, D. Pei and C. Liu. 2016. Effects of sowing and sowing time on the performance of the rotation of winter wheatsummer maize in the North China Plain. Ind. Crops Prod., 25: 239-247. https://doi. org/10.1016/j.indcrop.2006.12.003

Qasim, R., Z. Rafi and R. Ahmad. 2008. Wheat crop model based on water balance for agrometeorological crop monitoring. Pak. J. Meteorol., 2: 23-33.

Rukavin, H., I. Kolak, H. Sarcevic and Z. Satovic. 2002. Seed size, yield and harvest characteristics of three Croatin spring malting barleys. Die Bodenkultur., 53: 9-12.

Savin, R., P.J. Stone and M.E. Nicolas. 1996. Response of grain growth and malting quality of barley to short periods of high temperature in field studies using portable chambers. Aust. J. Agric. Res., 47: 465- 477. https://doi. org/10.1071/AR9960465

Shahwani, A.R., S.U. Baloch, S.K. Baloch, B. Mengal, W. Bashir, H.N. Baloch, R.A. Baloch,
A.H. Sial, S.A. Sabiel, K. Razzaq and A.A. Shahwani. 2014. Influence of seed size on germinability and grain yield of wheat (Triticum aestivum L.) varieties. J. Nat. Sci. Res., 4: 147155.

Shahzad, M.A., Wasi-ud-Din, S.T. Sahi, M.M. Khan, Ehsanullah and M. Ahmad. 2007. Effect of sowing dates and seed treatment on grain yield and quality of wheat. Pak. J. Agric. Sci., 44: 581-583.

Shirpurkar, G.N., N.V. Kashid and A.A. Pisal. 2007. Effect of different sowing dates and varieties on yield and yield attributes of wheat. Agric. Sci. Digest., 27: 68-70.

Sial, M.A., M.A. Arain, S. Khanzada, M.H. Naqvi, M.U. Dahot and N.A. Nizamani. 2005. Yield and quality parameters of wheat genotypes as affected by sowing dates and high temperature stress. Pak. J. Bot., 37: 575-584.

Steel, R.G.D., J.H. Torrie and D. Dickey. 1997. Principles and procedures of statistics: A biometrical approach. $3^{\text {rd }}$ Ed. McGraw Hill Book Co. Inc. New York, USA. pp. 172-177.

Stougaard, R.N. and Q.W.Xue.2004. Spring wheat seed size and seeding rate effects on yield loss due to wild oat (Avena fatua) interference. Weed Sci., 52: 133-141. https://doi.org/10.1614/ WS-03-007R1

Tahir, M., A. Ali, M.A., Nadeem, A. Hussain and F. Khalid. 2009. Effect of different sowing dates on growth and yield of wheat (Triticum aestivum $\mathrm{L}$.) varieties in district Jhang, Pakistan. Pak. J. Life Soc. Sci. 7(1): 66-69.

Timmermans, B.G.H., J. Vos, J.V. Nieuwburg, T.J. Stomph, P.E.L. Putten and L.P.G. Molendijk. 2007. Field performance of (Solanum sisymbriifolium), a trap crop for potato cyst nematodes. I. Dry matter accumulation in relation to sowing time, location, season and plant density. Ann. Appl. Biol., 150: 89-97. https://doi.org/10.1111/j.17447348.2006.00112.x

Zain, M., I. Khan, M.U. Chattha, R.W.K. Qadri, S.A. Anjum, M.U. Hassan, A. Mahmood and M. Ilyas. 2017. Foliar applied thiourea at different growth stages modulated late sown wheat. Pak. J. Sci., 69(1): 39-43.

Zareian, A., L. Yari, F. Hasani and G.H. Ranjbar. 2013. Field performance of three wheat (Triticum aestivum L.) cultivars in various seed sizes. World Appl. Sci. J., 16(2): 202-206. 